UDC: 616-089-06

\title{
PARAMETERS OF THE HEMODYNAMIC AFTER ABLATION ATRIAL FIBRILLATION AND/OR FLUTTER DEPENDING ON THE FUNCTIONAL CLASS OF CHRONIC HEART FAILURE
}

\author{
Tetyana Zolotarova ${ }^{1}$, Oleksander Bilchenko ${ }^{1,2}$ \\ ${ }^{1}$ V. N. Karazin Kharkiv National University, 6 Svobody Sq., Kharkiv, 61022, Ukraine, \\ e-mail: med@karazin.ua \\ ${ }^{2}$ Kharkiv Medical Academy of Postgraduate Education, 58 Amosova St., Kharkiv, 61176, Ukraine, \\ email: office@med.edu.ua
}

Evaluated parameters of the hemodynamic before and after ablation atrial fibrillation and/or flutter depending on the functional class of chronic heart failure in 74 patients. It was found that patients with the I functional class of chronic heart failure have significantly lower left atrium size compared to III functional class, which is associated with the better efficiency of the radiofrequency ablation in the remote period. Patients with the I and III functional class of chronic heart failure are having increasement of QTc duration in acute period of radiofrequency ablation that could be used as an independent predictor of arrhythmia recurrence. Patients with the I functional class chronic heart failure who failed drug therapy for atrial fibrillation and/or flutter alternative treatment in the form of the radiofrequency ablation should be considered as choice therapy.

KEY WORDS: parameters of the hemodynamic, atrial fibrillation, radiofrequency ablation, functional class, heart failure

\section{ПОКАЗНИКИ ГЕМОДИНАМІКИ ПІСЛЯ АБЛЯЦЇ̈ ФІБРИЛЯЦЇ̈ ТА/АБО ТРІПОТІННЯ ПЕРЕДСЕРДЬ В ЗАЛЕЖНОСТІ ВІД ФУНКЦІОНАЛЬНОГО КЛАСУ ХРОНІЧНОЇ СЕРЦЕВОЇ НЕДОСТАТНОСТІ}

Золотарьова Т. В. ${ }^{1}$ Більченко О. В. ${ }^{1,2}$

${ }^{1}$ Харківський національний університет імені В. Н. Каразіна, пл. Свободи, 6, м. Харків, 61022, Україна

1,2 Харківська медична академія післядипломної освіти, вул. Амосова, 58, м. Харків, 61176, Україна

Вивчені показники гемодинаміки до та після абляції при фібриляції та/або тріпотінні передсердь в залежності від функціонального класу хронічної серцевої недостатності у 74 хворих. Виявлено, що пацієнти I функціонального класу хронічної серцевої недостатності мають значно нижчий розмір лівого передсердя у порівнянні з III функціональним класом, що пов'язано з кращою ефективністю радіочастотної абляції у віддалений період. У пацієнтів I та III функціонального класу хронічної серцевої недостатності спостерігається збільшення тривалості QТс в гострому періоді радіочастотної абляції, що може використовуватися як незалежний предиктор рецидиву аритмії.

КЛЮЧОВІ СЛОВА: показники гемодинаміки, фібриляція передсердь, радіочастотна абляція, функціональний клас, серцева недостатність

\section{ПОКАЗАТЕЛИ ГЕМОДИНАМИКИ ПОСЛЕ АБЛЯЦИИ ФИБРИЛЛЯЦИИ И/ИЛИ ТРЕПЕТАНИЯ ПРЕДСЕРДИЙ В ЗАВИСИМОСТИ ОТ ФУНКЦИОНАЛЬНОГО КЛАССА ХРОНИЧЕСКОЙ СЕРДЕЧНОЙ НЕДОСТАТОЧНОСТИ}

Золотарева Т. В. ${ }^{1}$, Бильченко А. В. ${ }^{1,2}$

${ }^{1}$ Харьковский национальный университет имени В. Н. Каразина, пл. Свободы, 6, г. Харьков, 61022 , Украина

${ }^{2}$ Харьковская медицинская академия последипломного образования, ул. Амосова, 58, г. Харьков, 61176, Украина

Изучены показатели гемодинамики до и после абляции при фибрилляции и/или трепетании предсердий в зависимости от функционального класса хронической сердечной недостаточности у 74 
пациентов. Выявлено, что пациенты I функционального класса хронической сердечной недостаточности имеют значительно меньший размер левого предсердия по сравнению с III функциональным классом, что связано с лучшей эффективностью радиочастотной абляции в отдаленный период. У пациентов I и III функционального класса хронической сердечной недостаточности наблюдается увеличение продолжительности QТс в остром периоде радиочастотной абляции, которая может использоваться как независимый предиктор рецидива аритмии.

КЛЮЧЕВЫЕ СЛОВА: показатели гемодинамики, фибрилляция предсердий, радиочастотная абляция, функциональный класс, сердечная недостаточность

\section{INTRODUCTION}

Dilatation of right and left atrium is a common complication in atrial fibrillation/flutter (AF/AFL), especially in the long-term existence of these arrhythmias, due to a violation of the function of the left ventricle, leading to the development of chronic heart failure (CHF) and its progression according to growth of the functional class (FC). This suggests that AF/AFL can lead to significant morphological and functional changes in the heart [1-3]. Radiofrequency ablation (RFA) of arrhythmias in the right or left atrium is effective for the strategy of rhythm control, disappears or significantly reduces the number of arrhythmia paroxysms, which positively affects hemodynamic parameters of the heart, especially the size of the atrium, that is, it affects the risk of progression of CHF [3-6].

It seems expedient to study hemodynamic parameters in patients with $\mathrm{AF} / \mathrm{AFL}$ and $\mathrm{CHF}$ in the early postoperative period of RFA depending on FC CHF to determine which of them can affect the progression of CHF.

\section{OBJECTIVE}

To evaluate parameters of the hemodynamic after ablation atrial fibrillation and/or flutter depending on the functional class of chronic heart failure.

\section{MATERIALS AND METHODS}

On the basis SI «Zaycev V. T. Institute of General and Urgent Surgery NAMS of Ukraine», Kharkiv, Ukraine 74 patients were evaluated after RFA of AF/AFL at age $60.6 \pm 7.05((\mathrm{M} \pm \mathrm{sd}))$ (44 men and 30 women). Patients were divided into groups based on FC CHF (according to the New York Heart Association (NYHA)): 23 patients with CHF I FC, 32 - II FC, 19 - III FC. Patients IV FC CHF were absent.

Evaluated: heart rate (HR), pulse, systolic and diastolic blood pressure (SBP and DBP, respectively); electrocardiographic (ECG) characteristics - QRS, QTc; echocardiographic (ECHO) parameters: ejection fraction of left ventricle (LVEF), left ventricle end-diastolic diameter (LVED), left ventricle end-systolic diameter (LVES), left and right atrium size (LA and RA, respectively). For measuring the duration of the QT interval and subsequent calculation of QTc, the ECG was recorded on the computerized cardiologist Cardiolab + (HAI-Medica). The length of the corrected QT (QTc) was calculated using the Bazett formula: $\mathrm{QTc}=\mathrm{QT} /\left(\mathrm{RR}^{\wedge} 0.5\right)$, the accuracy of the measurement is $0.5 \mathrm{~ms}$. SBP and DBP were measured by the Korotkov method with the tonometer GAMMA 700k, accuracy of measurement $-1 \mathrm{~mm} \mathrm{Hg}$. ECHO study was performed on the apparatus Toshiba Applio 400. To calculate LVEF the Teichholz formula was used: $\mathrm{LVEF}=$

$\left((7 /(2.4+\mathrm{LVED})) \cdot \mathrm{LVED}^{\wedge} 3-(7 /(2.4+\mathrm{LVES})) \cdot\right.$ LVES $\left.^{\wedge} 3\right) /\left((7 /(2.4+\right.$ LVED $)) \cdot$ LVED $\left.\left.^{\wedge} 3\right)\right) \bullet 100 \%$.

Parameters were evaluated in FC CHF groups until and within 3-5 days after RFA.

The obtained data after the formation of the database was processed in Microsoft Excel, SPSS 17.0. For statistical evaluation of the results parametric criteria were used (mean value - M, standard deviation - sd), nonparametric criteria (absolute ( $\mathrm{n}$, number)). Reliability of the differences between groups was evaluated using the nonparametric MannWhitney U Test. The results were considered reliable at the significance levels $\mathrm{p}<0.05$. The Spirman correlation analysis (nonparametric), which shows the degree $\left(r_{s}\right)$ of the statistical dependence between the observation pairs, where $0>r_{s} \leq 0.5$ is a weak link, $0.5>r_{s} \leq 0.6$ - moderate, $0.6>r_{s} \leq 1-$ strong. The reliability of the obtained correlation coefficients was determined from the table «Standard correlation coefficients» based on the calculation of the number of degrees of freedom, followed by the definition of the critical value of the Spirman rank correlation coefficient, $\mathrm{p}<0.01$. 


\section{RESULTS AND DISCUSSION}

Table shows hemodynamic parameters in patients with AF/AFL in the acute period after ablation, depending on the functional class of CHF.

Parameters of the hemodynamic after ablation of AF/AFL depending on the FC CHF

\begin{tabular}{|c|c|c|c|c|c|c|c|}
\hline \multirow{2}{*}{\multicolumn{2}{|c|}{ Parameter }} & \multicolumn{2}{|c|}{ I FC CHF } & \multicolumn{2}{|c|}{ II FC CHF } & \multicolumn{2}{|c|}{ III FC CHF } \\
\hline & & $\begin{array}{c}\text { before } \\
\text { RFA }\end{array}$ & After RFA & $\begin{array}{c}\text { before } \\
\text { RFA }\end{array}$ & After RFA & before RFA & After RFA \\
\hline \multicolumn{2}{|c|}{$\mathrm{HR}(\mathrm{M} \pm \mathrm{sd}, 1 / \mathrm{min})$} & $\begin{array}{l}90.4 \pm \\
20.1^{*} \\
\end{array}$ & $\begin{array}{c}68.34 \pm \\
10.66 \\
\end{array}$ & $74.2 \pm 12.6$ & $\begin{array}{c}72.06 \pm \\
21.3 \\
\end{array}$ & $84 \pm 12.1^{*}$ & $69.3 \pm 11.67$ \\
\hline \multicolumn{2}{|c|}{$\begin{array}{c}\text { Pulse }(\mathrm{M} \pm \mathrm{sd} \\
1 / \mathrm{min})\end{array}$} & $\begin{array}{l}85.6 \pm \\
20.3^{*}\end{array}$ & $\begin{array}{c}68.01 \pm \\
10.66\end{array}$ & $73.2 \pm 12.8$ & $\begin{array}{c}72.08 \pm \\
21.6\end{array}$ & $82 \pm 14.2^{*}$ & $\begin{array}{c}69.01 \pm \\
11.69\end{array}$ \\
\hline \multirow[t]{2}{*}{$\begin{array}{c}\text { Atrerial } \\
\text { blood } \\
\text { pressure }\end{array}$} & $\begin{array}{c}\text { SBP (M } \\
\pm \mathrm{sd} \\
\mathrm{mmHg})\end{array}$ & $130 \pm 12.6$ & $\begin{array}{l}128 \pm \\
10.18\end{array}$ & $125 \pm 12.8$ & $\begin{array}{c}124.7 \pm \\
12.08\end{array}$ & $135 \pm 10.6$ & $\begin{array}{c}127.89 \pm \\
13.87\end{array}$ \\
\hline & $\begin{array}{c}\text { DBP (M } \\
\pm \mathrm{sd}, \\
\mathrm{mmHg})\end{array}$ & $82 \pm 6.2$ & $82 \pm 5.98$ & $80 \pm 7.14$ & $80 \pm 6.35$ & $81 \pm 6.35$ & $82.36 \pm 8.39$ \\
\hline \multicolumn{2}{|c|}{$\operatorname{LVEF}(\mathrm{M} \pm \mathrm{sd}, \%)$} & $\begin{array}{c}60.8 \pm \\
10.16 * *\end{array}$ & $\begin{array}{c}65.1 \pm \\
10.15 * *\end{array}$ & $60.1 \pm 7.02$ & $\begin{array}{c}59.65 \pm \\
7.02\end{array}$ & $\begin{array}{l}55.23 \pm \\
5.04 * *\end{array}$ & $\begin{array}{l}55.73 \pm \\
5.04 * *\end{array}$ \\
\hline \multicolumn{2}{|c|}{$\operatorname{LVED}(\mathrm{M} \pm \mathrm{sd}, \mathrm{cm})$} & $5.02 \pm 0.51$ & $5 \pm 0.51$ & $5.21 \pm 0.55$ & $5.20 \pm 0.55$ & $5.3 \pm 0.82$ & $5.3 \pm 0.82$ \\
\hline \multicolumn{2}{|c|}{$\operatorname{LVES}(\mathrm{M} \pm \mathrm{sd}, \mathrm{cm})$} & $3.4 \pm 0.51$ & $3.2 \pm 0.51$ & $3.5 \pm 0.58$ & $3.5 \pm 0.53$ & $3.7 \pm 0.56$ & $3.7 \pm 0.56$ \\
\hline \multicolumn{2}{|c|}{$\mathrm{LA}(\mathrm{M} \pm \mathrm{sd}, \mathrm{cm})$} & $\begin{array}{c}4.2 \pm 0.81 \\
\dagger\end{array}$ & $\begin{array}{c}4.1 \pm 0.81 \\
\dagger\end{array}$ & $4.4 \pm 0.47$ & $4.4 \pm 0.47$ & $5 \pm 0.57 \dagger$ & $4.9 \pm 0.57 \dagger$ \\
\hline \multicolumn{2}{|c|}{$\mathrm{RA}(\mathrm{M} \pm \mathrm{sd}, \mathrm{cm})$} & $4.1 \pm 0.75$ & $4.1 \pm 0.75$ & $\begin{array}{c}3.86 \pm \\
0.55 \dagger\end{array}$ & $\begin{array}{l}3.77 \pm \\
0.55 \dagger\end{array}$ & $4.5 \pm 0.75 \dagger$ & $4.5 \pm 0.75 \dagger$ \\
\hline \multicolumn{2}{|c|}{$\begin{array}{c}\text { QRS (M } \pm \mathrm{sd} \\
\mathrm{msec})\end{array}$} & $\begin{array}{c}91.75 \pm \\
11.03 \\
\end{array}$ & $\begin{array}{c}93.04 \pm \\
16.61 \\
\end{array}$ & $\begin{array}{c}90.7 \pm \\
13.54 \\
\end{array}$ & $92 \pm 15.12$ & $97 \pm 25.32$ & $96.3 \pm 15.31$ \\
\hline \multicolumn{2}{|c|}{ QTc $(\mathrm{M} \pm \mathrm{sd}, \mathrm{msec})$} & $\begin{array}{c}380 \pm \\
36.32 *\end{array}$ & $\begin{array}{c}424 \pm \\
33.37 *\end{array}$ & $\begin{array}{l}406 \pm \\
32.04\end{array}$ & $\begin{array}{l}407 \pm \\
39.74\end{array}$ & $398 \pm 55.16^{*}$ & $432 \pm 32.37 *$ \\
\hline
\end{tabular}

$M$ - average value; $n$ - number; sd - standard deviation; * $p<0,05$ before and after ablation inside of the groups of FC CHF; ** $p<0,01$ between groups of FC CHF; $† p<0,05$ between groups FC CHF.

Parameters as level of SBP and DBP, LVED, LVES, QRS have not significant difference, so FC CHF was not related to these indicators.

In I FC and III FC CHF, HR and pulse were significantly higher before ablation.

I FC CHF was associated with significantly higher LVEF both before and after RFA in comparison with III FC CHF.

LA and RA size were significantly lower in I FC CHF both before and after RFA compared to the III FC.

I FC and III FC CHF were associated with significantly incensement in $\mathrm{QT}_{\mathrm{c}}$ duration after RFA, in II FC CHF no such trend has been identified.

Below are correlations (Fig. 1-3a) between different pairs of observations, depending on FC CHF before and after ablation.
Accordingly, levels of communication strength are indicated by three types of lines: weak link - dotted line --------; moderate link - simple line _strong link - thick solid line

On the correlograms I FC CHF (both before and after ablation) were determined the appearance of strong connections between the SBP and DBP $\left(r_{s}=1,0 ; p<0,01\right)$; y II FC CHF - between LVES and LVEF, LVED $\left(r_{s}=0,7 ; p\right.$ $<0,01)$, was maintained between SBP and DBP $\left(r_{s}=0,62 ; p<0,01\right)$. Also for III FC CHF the maximum numbers of strong links has been clearly defined, especially new between LVEF and QRS $\left(r_{s}=0,64 ; p<0,01\right)$, LVES and LVED, RA $\left(r_{s}=0,66 ; p<0,01\right)$, LA and LVED $\left(r_{s}=0,65 ; p<0,01\right)$. There were no differences between periods of observation. 


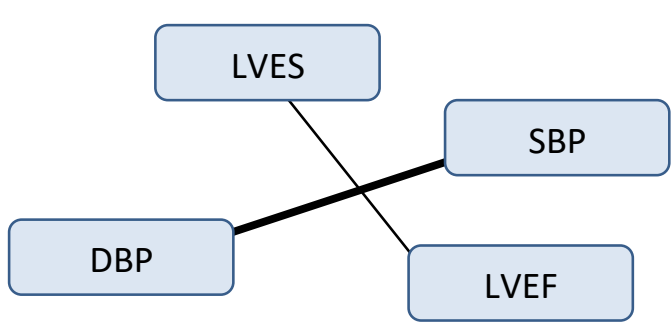

Fig.1. Correlogram for I FC CHF before RFA

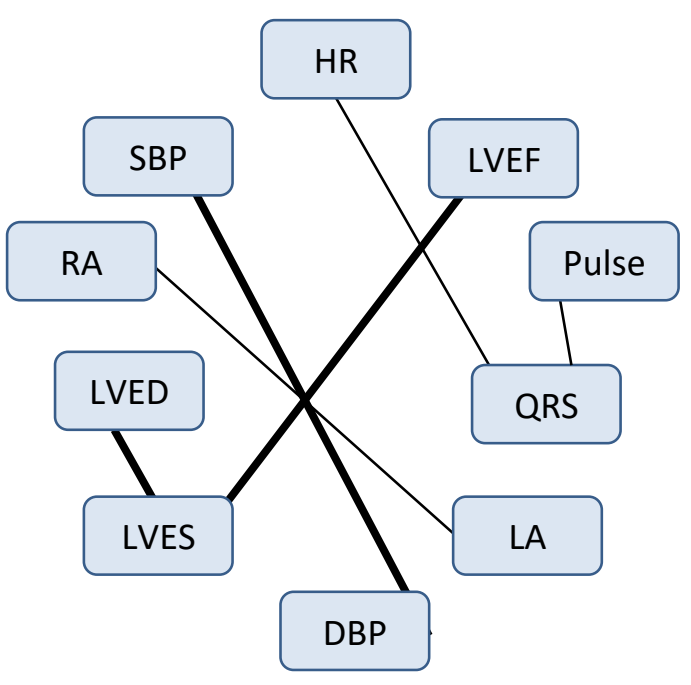

Fig.2. Correlogram for II FC CHF before RFA

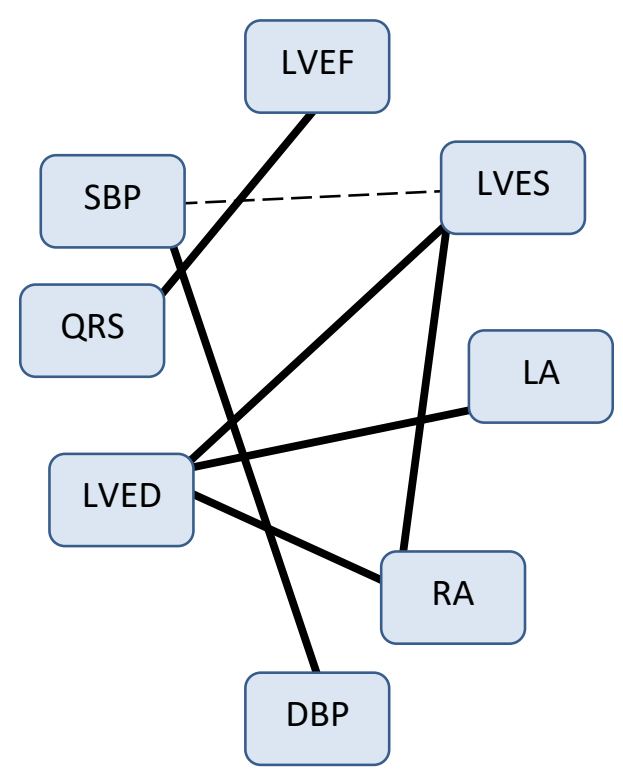

Fig.3. Correlogram for III FC CHF before RFA

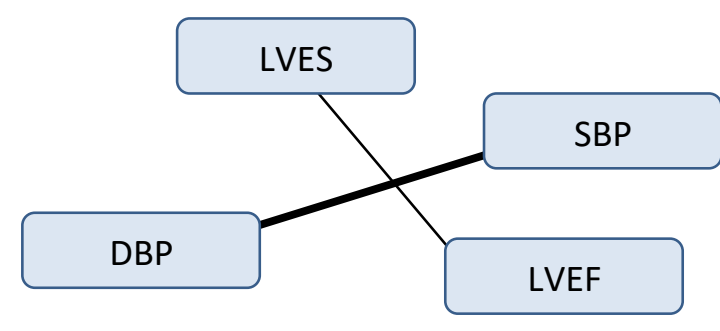

Fig.1a. Correlogram for I FC CHF after RFA

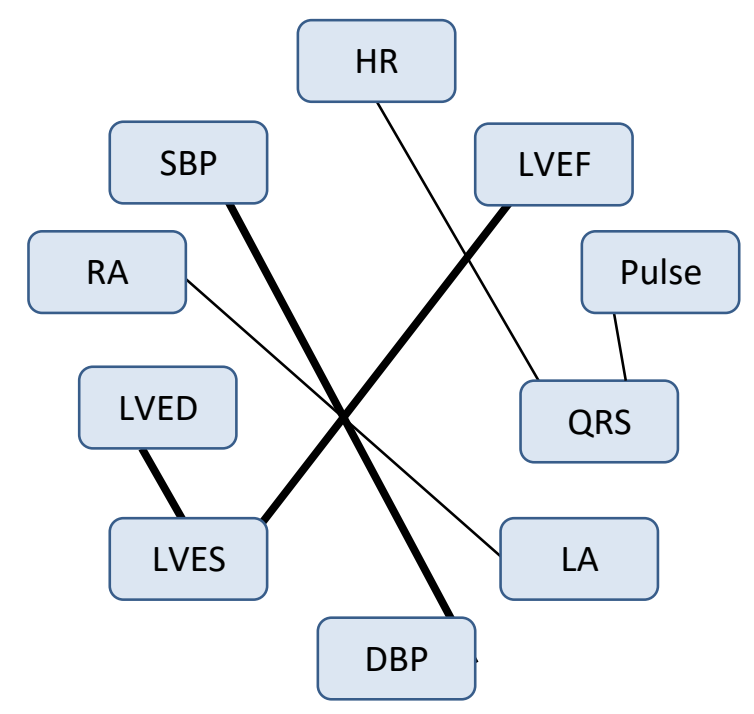

Fig.2a. Correlogram for II FC CHF after RFA

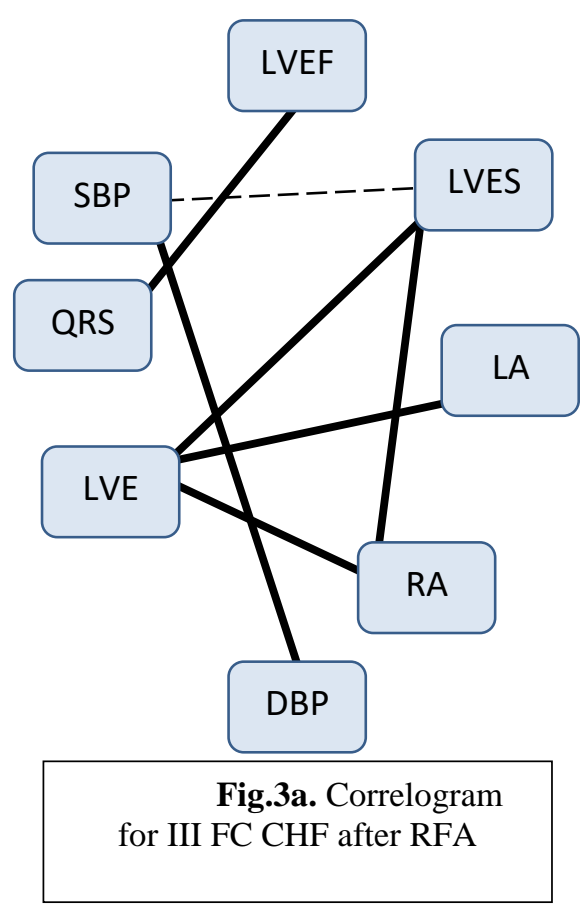


The size of the RA was a characteristic feature of the III FC CHF, which was noted in the study Luong C. and Xiao H. [7-8], as an important indicator for the development of recurrence of AF. Further researches are needed to clarify the impact of these indicators on the efficacy of RFA at various stages after intervention and the risk of CHF progression to a higher FC.

We showed that a smaller LA size was observed in I FC CHF, that was reflected in the study Park J.K. et al. [9-11], where it was shown that a smaller LA size was associated with a better outcome of RFA in the late period, probably due to fewer structural and hemodynamic changes in the heart.

Also, the dilatation of both atriums in the study Xiao H. B. et al. [8, 12-13] was associated with a poor prognosis in patients with $\mathrm{AF}$, which was confirmed in our study: the increase in atrial size was associated with an increase of FC CHF.

QTc interval could used as an independent predictor of arrhythmia recurrence [14-15]. Research of Ning Ma et al. showed that recurrent AF patients had a longer QTc interval than non-recurrent patients. Also, abnormal QT interval predicts AF because it reflects alterations in atrial refractoriness [16].

As a result of the correlation analysis, it was determined that there was a change in the number of correlations and an increase in the correlation between the indicators from I to III FC CHF, which showed a causal relationship, that is, one change led to a mandatory change of another indicator. According to our correlograms, it can be proposed that the dilatation of LA and RA with the background of inadequate treatment of arrhythmia led to the progression of CHF from a clinically insignificant course, such as patients I FC, to III FC CHF due to the dilatation of LV - an increase in LVED. Similarly, in patients with I FC CHF with poorly drug controlled arrhythmia alternative treatment as RFA should be considered as the choice of therapy as early as possible.

There are several limitations to our study. The observation was done in the acute period RFA, so it is not yet possible to reliably talk about the degree of RFA efficiency, however, parameters such as a size of the LA, RA, LVEF, duration QTc are required further monitoring in the delayed period and can serve as reliable predictors of arrhythmia.

\section{CONCLUSIONS}

1. The levels of heart rate and pulse decreases in I and III functional class of the chronic heart failure in the acute period radiofrequency ablation; systolic and diastolic blood pressure, QRS, left ventricle end-diastolic and left ventricle end-systolic diameter do not change after radiofrequency ablation.

2. Patient I and III functional class of the chronic heart failure are having increasement of QTc duration in acute period of radiofrequency ablation that could be used as an independent predictor of arrhythmia recurrence.

3. Patients with I functional class of the chronic heart failure have significantly lower left atrium size compared to III functional class of the chronic heart failure, which is associated with the best outcome of effectiveness of radiofrequency ablation in the late period.

\section{PROSPECTS FOR FUTURE STUDIES}

It is expedient to study the hemodynamics and features of the treatment of chronic heart failure, depending on the functional class in patients at various stages after interventional interventions for fibrillation and atrial flutter.

The research was carried out within the framework of the research work «Pharmacological and interventional approaches to the treatment of patients with heart rhythm disorders and arterial hypertension» (state registration number 0116U000973).

\section{REFERENCES}

1. Luong C. Atrial Fibrillation and Heart Failure: Cause or Effect? / C. Luong, M. Barnes, T. Tsang. // Current Heart Failure Reports. - 2014. - No. 11. - p. 463-470.

2. 2016 ESC Guidelines for the management of atrial fibrillation developed in collaboration with EACTS The Task Force for the management of atrial fibrillation of the European Society of Cardiology (ESC) [Electronic source] // European Heart Journal. - 2016. - Link: http://eurheartj.oxfordjournals.org/content/ehj/early/2016/09/08/eurheartj.ehw210.full.pdf

3. Worldwide Epidemiology of Atrial Fibrillation: A Global Burden of Disease 2010 Study / [S. Chugh, 
R. Havmoeller, K. Narayanan et al.]. // Circulation. - 2013. - No. 129. - P. 837-847.

4. Estimates of Current and Future Incidence and Prevalence of Atrial Fibrillation in the U.S. Adult Population / [S. Colilla, A. Crow, W. Petkun et al.]. // The American Journal of Cardiology. - 2013. No. 112. - P. 1142-1147.

5. Common atrial fibrillation risk alleles at $4 \mathrm{q} 25$ predict recurrence after catheter-based atrial fibrillation ablation / [M. Shoemaker, R. Muhammad, B. Parvez et al.]. // Heart Rhythm. - 2013. - No. 10. - P. 394400.

6. Radiofrequency catheter ablation is effective for atrial fibrillation patients with hypertrophic cardiomyopathy by decreasing left atrial pressure / [I. Hiroki, N. Yukiko, O. Noboru et al.]. // Journal of Arrhythmia. - 2017. - No. 33. - P. 256-261.

7. Right Atrial Volume Is Superior to Left Atrial Volume for Prediction of Atrial Fibrillation Recurrence After Direct Current Cardioversion / [C. Luong, D. J. Thompson, M. Bennett et al.]. // The Canadian journal of cardiology. - 2015. - No. 31. - P. 29-35.

8. The association of chronic atrial fibrillation with right atrial dilatation and left ventricular dysfunction in the elderly / H.Xiao, S. Rizvi, D. McCrea, B. Kaufman. // Medical science monitor: international medical journal of experimental and clinical research. - 2004. - No. 10. - P. 16-20.

9. Good responders to catheter ablation for long-standing persistent atrial fibrillation: Clinical and genetic characteristics / [Park J., Lee J., Yang P. et al.]. // Journal of Cardiology. - 2017. - No. 69. - P. 584-590.

10. Functional class of chronic heart failure and clinical features of patients with permanent pacemakers / I. M. Kolomytseva, D. E. Volkov, D. O. Lopin, M. I. Yabluchansky. // The Journal of V. N. Karazin Kharkiv National University, series «Medicine». - 2014. - No. 27. - P. 5-9.

11. Associations between cardiac fibrosis and permanent atrial fibrillation in advanced heart failure. / [B. Aldhoon, T. Kučera, N. Smorodinová et al.]. // Physiological research. - 2013. - No. 62. - P. $247-255$.

12. Right atrial indexed volume in healthy adult population: reference values for two-dimensional and threedimensional echocardiographic measurements / [J. Moreno, L. Perez de Isla, N. Campos et al.]. // Echocardiography. - 2013. - No. 30. - P. 667-671.

13. Genetic loci associated with atrial fibrillation: relation to left atrial structure in the Framingham Heart Study / [J. Magnani, X. Yin, D. McManus et al.]. // Journal of the American Heart Association. - 2014. No. 3. - P. e000616-e000616.

14. QTc interval predicts outcome of catheter ablation in paroxysmal atrial fibrillation patients with type 2 diabetes mellitus / Ning Ma, Xiao-yan Wu, Chang-sheng Ma et al.]. // Journal of Huazhong University of Science and Technology. - 2016. - No. 36(5). - P. 646-652.

15. Functional parameters of blood circulation in first three months after radiofrequency ablation of atrial fibrillation and flutter / [M. Brynza, A. Bilchenko, E. Makharynska et al.]. // Georgian medical news. 2018. - No. 279. - P. 73-79.

16. The QT interval as a Noninvasive Marker of Atrial Refractoriness / [K. Nguyen, R. Gladstone, J. Dukes et al.]. // Pacing and clinical electrophysiology. - 2016. - No. 39(12). - P. 1366-1372. 